\title{
Differences of Students' Learning Outcomes in Parallel Classes on Basic Chemistry I Subject at Chemistry Education Study Program FKIP UNTAD
}

\author{
Ratman \\ Universitas Tadulako \\ Palu, Indonesia \\ ratmanut@gmail.com
}

\author{
Daud Karel Walanda \\ Universitas Tadulako \\ Palu, Indonesia
}

\begin{abstract}
The ability of new students is a basic knowledge possessed before the further learning process activities. The initial ability of students can be seen from the results of the selection of a university entrance exam scores of the national and TOEFL score. The purpose of this study was to describe the learning outcomes of students who take courses in basic chemistry I and to explain the differences of students' learning outcomes in parallel classes in terms of initial ability on the subject basic chemistry I. Samples were chemistry student academic year 2016/2017 $n_{1}=49, n_{2}=45$. This research was quasi-experimental research. The design of systematic research in this study was a non-equivalent group, post-test only design. Testing research data used statistical analysis t-test (independent sample t-test) with the prerequisite test is a test of normality and homogeneity test. The students' result was collected from the mid-test (UTS), final-test (UAS), activities and practicum. Learning outcomes $E_{1}$ was $M=74.65$, and learning outcomes $E_{2}$ was $M=67.65$. Based on the statistical analysis of the hypothesis with the t-test values collected $t(92)$ was 10.179 and was located on the rejection of $\mathrm{H}_{0}$ is $\mathbf{- 1 . 9 8 6}$ and $\mathbf{1 . 9 8 6}$. These results suggest that there are differences of learning students' outcomes in parallel classes in terms of initial ability on the subject basic chemistry I of students of Chemistry Education Study Program FKIP UNTAD.
\end{abstract}

Keywords-Students' learning outcomes, ability of students, basic chemistry I, TOEFL score

\section{INTRODUCTION}

The paradigm of competency-based education includes curriculum, pedagogy, and assessment that emphasize on standards or outcomes. The curriculum contains teaching materials to the students through the learning process [1]. Basic Chemistry Course $I$ is a compulsory subject that is programmed in the first semester. The subject topics in Basic Chemistry I consists 6 topics such as material and periodic system, molecular structure, stoichiometry, thermochemistry, form of substances and chemical equilibrium. Students are expected to understand the basics of chemistry for example particulate matter and how to measure it, atomic structure and how to classify, changes, and conditions of equilibrium and the accompanying energy. The learning process is implemented by using pedagogy that includes strategies or methods of teaching. The success rate of learning achieved by students can be seen on learning outcomes, which include exams, assignments and practical work. Thus, the success of learning chemistry is not only determined by the student, but the role of the teacher in managing learning is also crucial [2].

Chemistry education courses in the academic year 2016/2017 reached the number of students who did not conform to the ideal capacity of each class, so accommodated in parallel classes based on prior knowledge of students. Parallel classes were several different classes at the same level. Determination of parallel classes based on ability early through the college admission, the value of the UN and TOEFL score. The result of inferential analysis indicates that the learning strategy and academic capability influenced the metacognitive ability students. The average score metacognitive ability remarks in the RT+TPS was 77.73 and the higher $1.65 \%$ than TPS with remarks 76.44 , but the really different and the higher $2.92 \%$ than RT with remarks 75.45 , $4.33 \%$ than the conventional with remarks 74.36 . The average score met cognitive ability remarks Up students academic capability performs 76.53 , that was the really different and the higher $1.39 \%$ than the Down student academic capability performs is 75.46. The average score RT+TPS strategy learning in the Up academic capability with the remarks 78.93 and the higher $1.42 \%$ than TPS-Up academic with remarks 77.82 , but the really different and the higher $4.86 \%$ than RT Up academic with remarks $75.10,5,91 \%$ than the Conventional-Up academic with remarks 74.27. The average score metacognitive ability strategy learning RT+TPS-Up academic was really different and higher $3.05 \%$ than RT+TPS-Down academic with remarks 76.53. The RT+TPS strategy learning application has the best result to increase the metacognitive ability in learning biology if it is compared with the RT, TPS or Conventional strategy learning on the Up or Down students academic capability performs. This strategy can be used for the largest biology learning and as the alternative to managing the instruction learning in the class, the factor fundamental to make the decision for the stakeholders, and the first research for the references continuous research [1]. 
Differences in the initial ability of students are due to differences in the way of learning. How learning is a way of how students carry out learning activities such as how they prepare to learn, to learn, independent learning activities are carried out, they learn patterns, how to take the exams. The quality of learning will determine the quality of learning outcomes obtained. How good learning will lead to successful learning, learning how bad otherwise would lead to less success or failure of learning [3]. Student learning is carried out activities of students in certain learning situations, these activities are a reflection of learning to do business. How to learn is a problem faced by every student and must be addressed properly so as not to interfere with the success of the study. The problems include, difficulty set the time, laziness to read a book, ignorance of the lessons learned, the difficulties follow and memorize the lesson or when exams. Of the many ways, here are some important methods, namely: 1) regularity in learning, 2) How to read a book, 3) How to make a summary, 4) How to follow the lessons, 5) How to memorize the lesson, 6) How to take the exam [4].

General principles in [5] which must be made guidance in implementing the learning process, namely: 1) Learning in essence have a purpose. 2) The basis of learning is something explorative as well as finding and not a repetition of routine. 3) The results of learning achieved always bring knowledge and understanding and cause a reaction or response that is understandable and reasonable. 4) The results of the study are not tied to a situation but can also be used in other situations. 5) The learning process has always been a process of experience, namely interaction individual, and his environment. 6) The results of the study should be used, which means that knowledge and skills can be immediately used in a life situation. 7) The learning process should always be adapted to the individual differences that are learned [5].

\section{METHOD}

This type of research was quantitative descriptive. Samples were chemistry student academic year 2016-2017 $\quad\left(\mathrm{n}_{1}=49\right.$, $\left.\mathrm{n}_{2}=45\right)$. This research was quasi-experimental research. The design of systematic research in this study was a nonequivalent group, post-test only design. Testing research data using statistical analysis t-test (Independent sample t-test) with the prerequisite test was a test of normality and homogeneity test. Student results collected from the mid-test (UTS), finaltest (UAS), activities and practicum. Pinpointing the source of data on the qualitative research was purposive, which was determined by adjusting the research objectives or goals [6]. A method of data collection in this research was achievement test. Data analysis was using Independent t-tests.

\section{RESULTS AND DISCUSSION}

TABLE 1. GROUP STATISTIC

\begin{tabular}{|c|c|c|c|c|}
\hline & Initial Ability & $\mathbf{N}$ & Mean & $\begin{array}{c}\text { Standard } \\
\text { Deviation }\end{array}$ \\
\hline \multirow{2}{*}{$\begin{array}{c}\text { Learning } \\
\text { Outcomes }\end{array}$} & High & 49 & 80.69 & 5.444 \\
\cline { 2 - 5 } & Low & 45 & 70.66 & 3.914 \\
\hline
\end{tabular}

TABLE 2. INDEPENDENT SAMPLE TEST

\begin{tabular}{|c|c|c|c|c|c|c|c|c|c|c|}
\hline & \begin{tabular}{|r} 
Leven \\
for Eq \\
Vari
\end{tabular} & $\begin{array}{l}\text { Test } \\
\text { lity of } \\
\text { ces }\end{array}$ & \multicolumn{7}{|c|}{ t-test for Equality of Means } \\
\hline & & \multirow[t]{2}{*}{$\mathbf{F}$} & \multirow{2}{*}{ Sig. } & \multirow{2}{*}{$\mathbf{T}$} & \multirow{2}{*}{ Df } & \multirow{2}{*}{$\begin{array}{c}\text { Sig. } \\
(2- \\
\text { tailed } \\
)\end{array}$} & \multirow{2}{*}{$\begin{array}{l}\text { Mean } \\
\text { Differ } \\
\text { ence }\end{array}$} & \multirow{2}{*}{$\begin{array}{c}\text { Std. } \\
\text { Err } \\
\text { or } \\
\text { Diff } \\
\text { ere } \\
\text { nce }\end{array}$} & \multicolumn{2}{|c|}{\begin{tabular}{c}
\multicolumn{1}{c}{$95 \%$} \\
Confidence \\
Interval of \\
Difference \\
\end{tabular}} \\
\hline & & & & & & & & & $\begin{array}{l}\text { Lo } \\
\text { wer }\end{array}$ & $\begin{array}{l}\text { Up } \\
\text { per }\end{array}$ \\
\hline \multirow{2}{*}{$\begin{array}{c}\text { Lear- } \\
\text { ning } \\
\text { Out- } \\
\text { comes }\end{array}$} & $\begin{array}{c}\text { Equal } \\
\text { varian } \\
\text { ces } \\
\text { not } \\
\text { assum } \\
\text { ed }\end{array}$ & 4.113 & .045 & $\begin{array}{c}10.1 \\
79\end{array}$ & 92 & .000 & $\begin{array}{c}10.0 \\
32\end{array}$ & .986 & $\begin{array}{c}8.07 \\
5\end{array}$ & $\begin{array}{c}11.9 \\
90\end{array}$ \\
\hline & $\begin{array}{c}\text { Equal } \\
\text { Varia } \\
\text { nces } \\
\text { assum } \\
\text { ed }\end{array}$ & & & $\begin{array}{c}10.3 \\
19\end{array}$ & $\begin{array}{c}87.1 \\
29\end{array}$ & .000 & $\begin{array}{c}10.0 \\
32\end{array}$ & .972 & $\begin{array}{c}8.10 \\
0\end{array}$ & $\begin{array}{c}11.9 \\
64\end{array}$ \\
\hline
\end{tabular}

The results of two different test analysis using statistic, average summarized in Table 1. Based on data analysis showed $t_{\text {test }}$ not be among the top range $t_{\text {table }}$ and $t_{\text {minus }}$, Ho rejected, it means that there are differences in average significantly between these two classes. Based on the calculation results of the test the average difference between the two experimental classes 1 and 2 by using the experimental test two parties, the price obtained $t_{\text {test }} 10.179$ and $t_{\text {table }} 1.986$ prices with $\mathrm{df}=92$ and $\alpha=5 \%$. Because the value is not on $t_{\text {table }} t_{\text {cal }}$ and $t_{\text {minus }}$ it can be concluded that there are differences in learning outcomes between the experiment class 1 and experiment 2 . These results concur with those of Racham and Hartono that mathematics learning achievement of students majoring in Mathematics and Science education can be predicted through prior knowledge of students. In addition to the student activity data obtained through face to face also higher [7].

This is due to the communication between students with high ability over the experimental class 1 well, in comparison with the class of the class with low ability in experiment 2. Data results of student learning good experimental class 1 UTS, UAS and practical value on average higher than the value of the class experiment 2 . These results indicate that the results of classroom learning with high initial capability better than classes with lower initial ability. Students with high ability are happy to help their friend of the group who do not understand. There is a sense of satisfaction when they can help their friends who do not understand. Low-ability students who are pleased to help their friend in explanation material of the group and they feel no ashamed to ask. Usually, if they are less understood, they do not take personal and not ashamed to ask to lecturers [8].

Lack of interest and attention of students during the learning process became obvious when the observation in the classroom. At the beginning of the learning process, students were enthusiastic about the subject matter provided. But after learning activity lasts long enough, there are some students 
who are beginning to look tired of the subject matter provided. Boredom in students is very evident when students are asked to discuss or work on the problems. There are some students who are more likely to see each other's answers without even trying to work on the problems themselves [9]. Student readiness in accepting a material will greatly affect the student's level of understanding. If before receiving a psychological state of matter and the student's mind was ready, the students will be easier to accept the new concept given by the teacher. If the student is not ready or even not ready to accept the material given by the teacher, then the response given students in accepting new concepts are not optimal, thus enabling a lack of understanding of students and possible misconceptions about the concept receive.

\section{CONCLUSION}

Based on the statistical analysis of the hypothesis with the $\mathrm{t}$-test values collected $\mathrm{t}(92)=10.179$ and is located on the rejection of $\mathrm{H}_{0}$ is -1.986 and 1.986 . These results suggest that there are differences of learning students outcomes in parallel classes in terms of initial ability on the subject basic chemistry I of students of Chemistry Education Study Program FKIP UNTAD.

\section{ACKNOWLEDGMENT}

The authors say many thanks to family, friends, and collegues.

\section{REFERENCES}

[1] N. Efendi, "Pengaruh Pembelajaran Reciprocal Teaching Dipadukan Think Pair Share Terhadap Peningkatan Kemampuan Metakognitif Belajar Biologi Siswa SMA Berkemampuan Akademik Berbeda di Kabupaten Sidoarjo," J. Santiaji Pendidik., vol. 3, no. 2, pp. 85-109, 2013.

[2] N. Hidayati, D. Sulistyani, and D. T. Rahardjo, "Perbedaan Hasil Belajar Siswa Antara Menggunakan Media Pocket Book dan tanpa Pcket Book pada Materi Kinematika Gerak Melingkat Kelas X," J. Pendidik. Fis., vol. 1, no. 1, pp. 164-172, 2013.

[3] T. L. Gie, Cara Belajar yang Efisien. Yogyakarta: Liberty, 1987.

[4] M. Y. Mappeasse, "Pengaruh Cara Dan Motivasi Belajar Terhadap Hasil Belajar Programmable Logic Controller ( Plc ) Siswa Kelas Iii Jurusan Listrik Smk Negeri 5 Makassar,” J. Medtek, vol. 1, no. 2, pp. 1-6, 2010.

[5] T. Rusyan, A. Kusdinar, and Z. Arifin, Pendekatan dalam Proses Belajar Mengajar. Bandung: Remadja Karya Offset, 1989.

[6] Wahyujaya, Y. Koesmaryono, and F. Yulianda, "Kajian Sistem Pembelajaran Sebagai Upaya Peningkatan Sistem Penjaminan Mutu," J. Kependidikan, vol. 45, no. 1, pp. 90-104, 2015.

[7] F. A. Rachman and Hartono, "Hubungan Kemampuan Awal dan Sikap terhadap MIPA dengan Prestasi Belajar MIPA Mahasiswa Jurusan Pendidikan MIPA,” J. Ilmu Pendidik., vol. 3, no. 3, pp. 228-235, 1996.

[8] M. L. Dewi, "Belajar Kelompok Model STAD dan JIGSAW untuk Meningkatkan Motivasi dan Keaktifan Mahasiswa," J. Ilmu Pendidik., vol. 15, no. 3, pp. 182-192, 2008.

[9] R. A. Marsita, S. Priatmoko, and E. Kusuma, “Analisis Kesulitan Belajar Kimia Siswa SMA dalam Memahami Materi Larutan Penyangga dengan Menggunakan Two-Tier Multiple Choice Diagnostic Instrument," J. Inov. Pendidik. Kim., vol. 4, no. 1, pp. 512-520, 2010. 